\title{
Study and Redesign of Aircooler System in a 16 MW Steam Turbine Surface Condenser at Neka Power Plant
}

\author{
Edris Ghonoodi*, Mofid Gorji Bandpy \\ Department of Mechanical Engineering, Babol University of Technology, Babol, Iran \\ Email: *e.ghonoodi@gmail.com,gorji@nit.ac.ir
}

How to cite this paper: Ghonoodi, E. and Gorji, M. (2021) Study and Redesign of Aircooler System in a 16 MW Steam Turbine Surface Condenser at Neka Power Plant. Journal of Power and Energy Engineering, 9, 61-75.

https://doi.org/10.4236/jpee.2021.97005

Received: May 18, 2021

Accepted: July 26, 2021

Published: July 29, 2021

Copyright ( 2021 by author(s) and Scientific Research Publishing Inc. This work is licensed under the Creative Commons Attribution International License (CC BY 4.0).

http://creativecommons.org/licenses/by/4.0/

\begin{abstract}
According to the study of basic Rankin thermal cycle, the steam exhaust pressure of a typical steam turbine toward the condenser, plays a great role in the efficiency and the net output power of the steam turbine, so most surface condensers that are working in thermal power plants are kept at vacuum condition so that the maximum power of thermal cycle can be achieved. The vacuum pressure at condenser leads to the entering of air and Non-condensable gases from turbine gland seals to condenser so that the special air ejection equipment is being used to take apart air from steam and vent it to out of condenser. In this study, a special steam and air separator mechanism in an evacuating system called "Aircooler" at a $16 \mathrm{MW}$ steam turbine condenser is being studied and the Fluent CFD software is utilized to analyze the behavior of steam plus air in a typical aircooler system of $16 \mathrm{MW}$ steam turbine condenser of Neka power plant to find a way to reduce the risk of cooling tube rupture in aircooler ducts. The critical condition which tube rupture happens is determined and it is demonstrated that in hot seasons of year, by increasing the seawater cooling temperature and increasing in turbine steam exhaust pressure and temperature, the risk of tube rupture due to more mixture velocity at the first row of aircooler cooling tubes increases and also the effect of tube plugged condition on the performance of aircooler shows that the risk of other tubes rupture will increase and thus the efficiency of aircooler decreases due to more aircooler exhaust temperature. Finally, two modified plans at aircooler system design will be studied and simulated via Fluent CFD software which leads to reduce the risk of tube rupture. The results show that by modification of aircooler ducts and holes, the mixture air and steam flow velocity to first aircooler cooling tube row decreases significantly and causes the risk of tube rupture to decrease remarkably and also the exhaust temperature of aircooler decreases and causes the higher ejector performance.
\end{abstract}




\section{Keywords}

Aircooler, CFD, Condenser, Ducts, Tube Rupture, Exhaust Pressure, Exhaust Temperature, Mixture Flow

\section{Introduction}

According to Figure 1, the surface condenser pressure in a typical Rankin thermal cycle plays a great role in the efficiency and output power of turbine. The less the pressure of condenser causes the more efficiency and net power output of cycle so in most cases the condenser pressure is subjected to keep at vacuum condition [1].

To reduce the pressure of condensers in the steam side section, special ejector equipment is being used so that with aim of steam or water jet through a nozzle, a definite vacuum is prepared thus it can suck the trapped air in condenser and make a proper vacuum inside the steam side of condenser. Special equipment which is called "Aircooler" is placed inside of condenser steam side which the suction of gases in condenser takes place via this system which first the mixture of steam with air and non-condensable gases are being sucked through this system and then the steam inside the mixture will be condensed by passing through some cooling tubes and finally, the remaining gases will be vented out of condenser.

The CFD simulation of steam condensation with presence of air has been studied by researchers over last 30 years. Lux et al. [3] presented a computer model that could predict the performance of a condensing heat exchanger with circular tubes. This model ignored the effect of condensation and diffusion processes. Malalasekera et al. [4] used CFD to model the heat transfer and the flow in the secondary heat exchanger of a condensing boiler. However, the diffusion process of water vapor in non-condensing gases and water-vapor condensation was not considered in his work. Valencia [5] carried out a CFD simulation for the condensation of water vapor and acids on the plate using a commercial code, FLUENT, and a user-defined subroutine. A new mechanistic model for the prediction of condensation in the presence of non-condensable gas using a commercial computational fluid dynamic code, CFX-4, was presented by Karkoszka and Anglart [6]. The model was based on a solution of the conservation equation

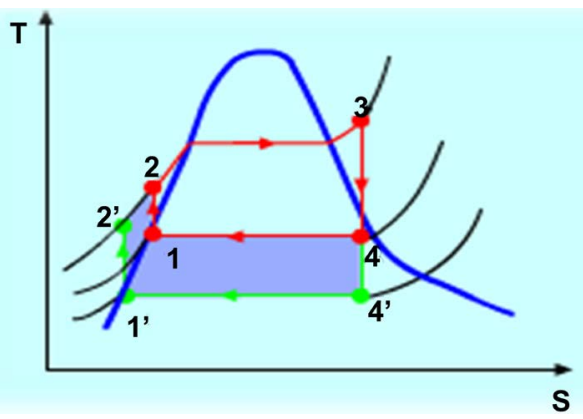

Figure 1. Condenser pressure effect on typical Rankin cycle [2]. 
for the vapor phase and the transport equation for the non-condensable gas. Ambrosini et al. [7] used the commercial CFD code FLUENT ${ }^{\circledR}$ for the numerical simulation of condensation of an air-steam mixture on a flat wall in a vertical square channel. Benelmir, Mokraoui and Souayed [8] performed a simulation of water-vapor condensation in the presence of non-condensable gas between two vertical plane plates and in a plate fin-and-tube heat exchanger in a stationary mode using FLUENT software and finally, Mohammad Saraireh [9] used FLUENT CFD method to solve Condensation of water vapor from humid air in compact heat exchangers.

In this study, the FLUENT CFD software is used to analyze the behavior of steam plus air in a typical aircooler system of $16 \mathrm{MW}$ steam turbine condenser of Neka power plant to find ways to reduce the risk of cooling tube rupture in aircooler ducts.

\section{Problem Description}

In Neka power plant's auxiliary condenser, a special aircooler system is accomplished inside the condenser steam side which is directly connected to ejector suction line where via this system air with non-condensable gases and also steam is sucked inside the aircooler ducts and then after passing through the cooling tubes the steam condenses and returns to condenser while remaining gases sucked toward the ejector [10] (Figure 2 \& Figure 3).

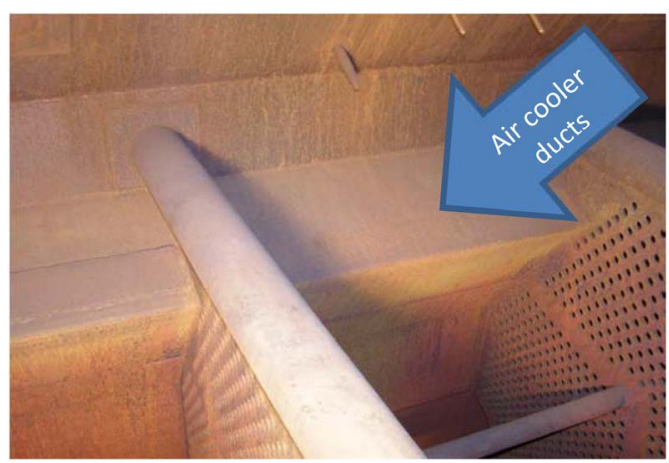

Figure 2. Aircooler ducts in condenser.

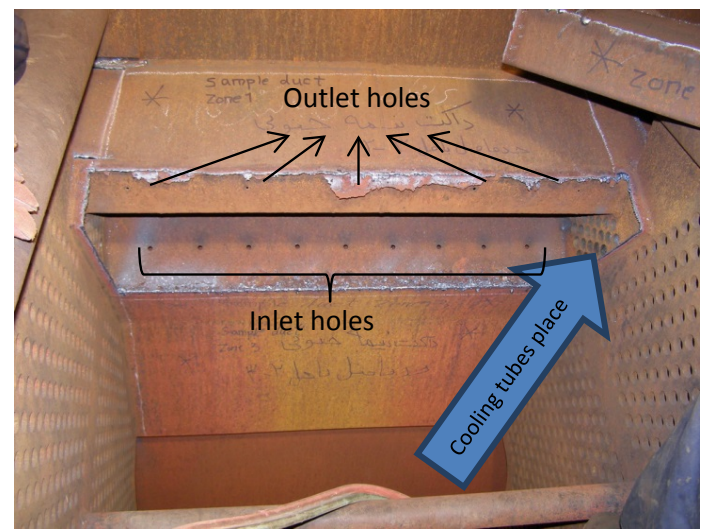

Figure 3. Aircooler zone in condenser. 

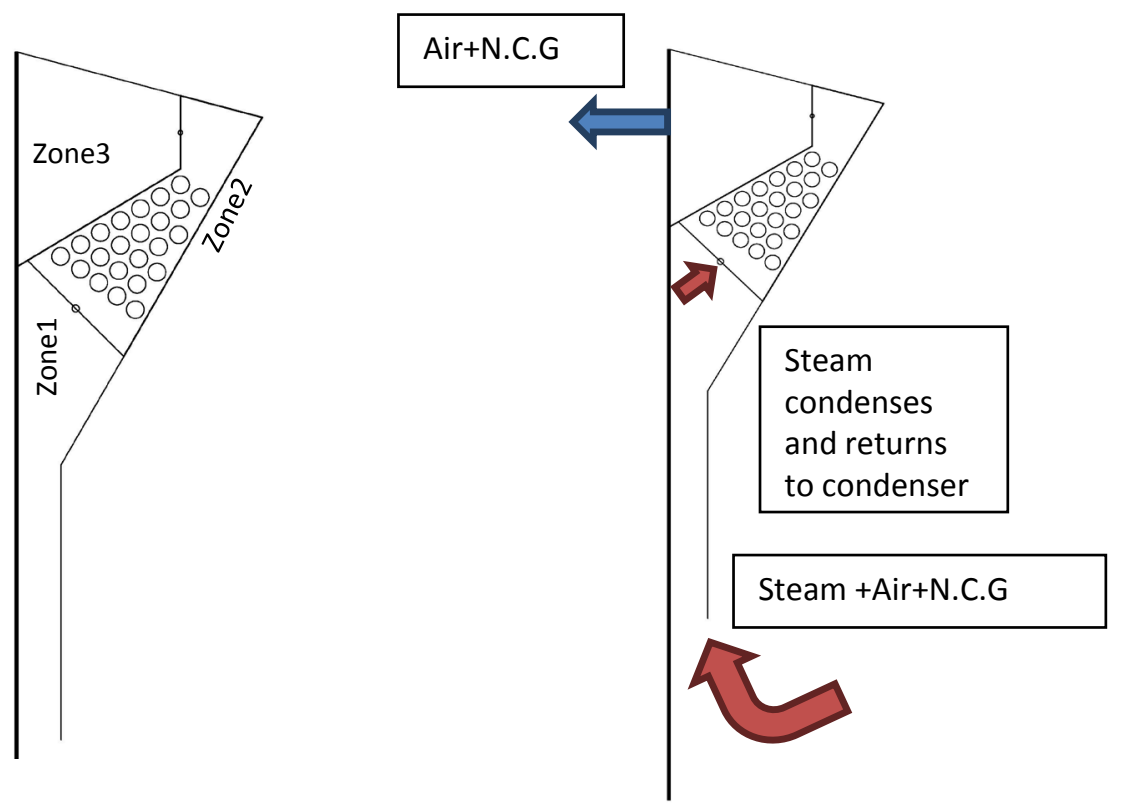

Figure 4. Aircooler zone schematic in condenser.

As described in Figure 4, the aircooler ducts consist of three zones where at first zone the mixture of air and steam enter, and in the second zone the mixture enters through $9.8 \mathrm{~mm}$ holes and then the steam condenses while passing through the 23 cooling tubes and then the remaining air will be vented out to zone 3 from $6.1 \mathrm{~mm}$ holes and then to ejector suction line.

In hot seasons of year some tubes of first aircooler row are encountered with rupture problem which leads to shutdown of turbine and condenser to plug the ruptured tube. This phenomenon causes the low reliability of using both turbine and condenser and also the more plugged tubes causes the lower zone 2 performance which increases the risks of other tube rupture and also causes the increasing in the temperature of aircooler exhaust that can lower the performance of ejector.

The tube material is Aluminum-Brass and Caspian Seawater is used as a cooling fluid flow inside the $24 \mathrm{~mm}$ diameter of tubes.

The sample tube considerations and tests at lab showed that the rupture event is mainly related to dezincification phenomena where the jet of steam plus air and non-condensable gases at the entrance of zone 2 will ruin the surface zinc of the first cooling tubes row at the aircooler and after a while, this matter cause the tube rupture.

The ruptured tubes are shown in Figure 5.

Fluent software is used to consider the main reasons of tube rupture so that:

1) Analyze the effects of cooling tubes temperature and also condenser condition (the turbine steam exhaust temperature and pressure) on the performance of aircooler;

2) Find the critical condition at which the tube rupture would happen;

3) Redesign the aircooler ducts so that the risk of tube rupture decreases. 


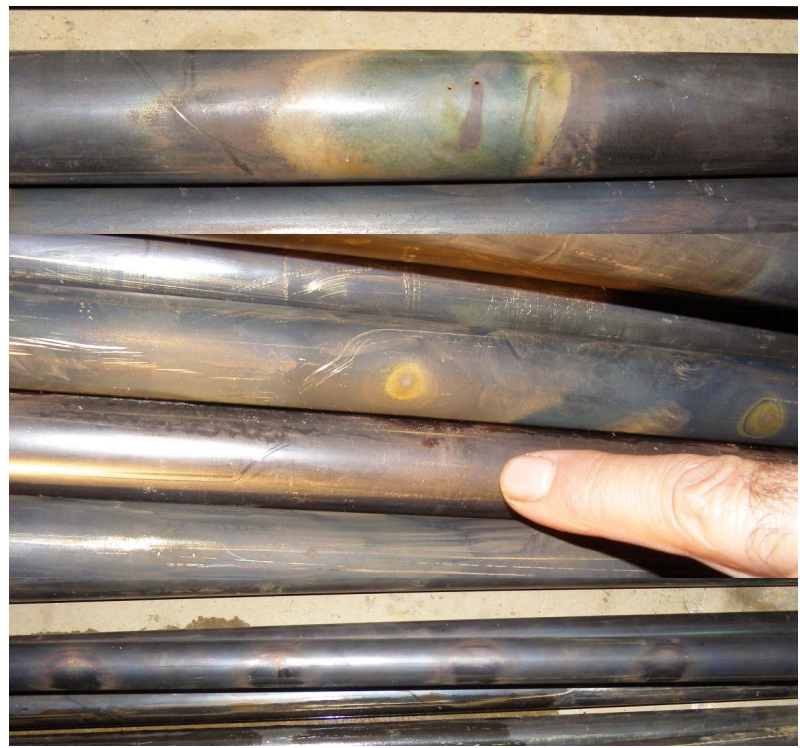

Figure 5. Tube rupture in aircooler zone 2.

\section{Governing Equations}

\subsection{Abbreviations and Acronyms}

\begin{tabular}{|c|c|c|c|}
\hline$\rho$ & density & $G_{k}$ & $\begin{array}{l}\text { generation of turbulent kinetic } \\
\text { energy due to the mean velocity gradients }\end{array}$ \\
\hline$\varepsilon$ & dissipation & $G_{b}$ & $\begin{array}{c}\text { generation of turbulence } \\
\text { kinetic energy due to buoyancy }\end{array}$ \\
\hline$\alpha_{\varepsilon}$ & inverse effective Prandtl numbers for $\varepsilon$ & $S_{\varepsilon}$ & Energy user-defined source terms. \\
\hline$\alpha_{k}$ & inverse effective Prandtl numbers for $k$ & $S_{k}$ & Energy user-defined source terms. \\
\hline$C_{1 \varepsilon}$ & constant in Equation (1) & $\mu_{e f f}$ & effective viscosity \\
\hline$C_{2 \varepsilon}$ & constant in Equation (1) & $\tau$ & stress tensor \\
\hline$C_{3 \varepsilon}$ & constant in Equation (1) & E & Energy \\
\hline$t$ & time & $k$ & turbulence energy \\
\hline$h_{f g}$ & Latent heat antalpy & $Q_{l}$ & latent heat \\
\hline$Q_{s}$ & sensible heat & $H_{a v}$ & the overall HTC \\
\hline
\end{tabular}

\subsection{Equations}

In simulating of aircooler system a turbulent kinematic energy model is being used as a " $k$ " and " $\varepsilon$ " (RNG) type witch governing equations are the same as Equation (1) and Equation (2).

$$
\begin{gathered}
\frac{\partial}{\partial t}(\rho \varepsilon)+\frac{\partial}{\partial x_{i}}\left(\rho \cdot \varepsilon \cdot u_{i}\right) \\
=\frac{\partial}{\partial x_{j}}\left(\alpha_{\varepsilon} \mu_{e f f} \frac{\partial \varepsilon}{\partial x_{j}}\right)+C_{1 \varepsilon} \frac{\varepsilon}{k}\left(G_{k}+C_{3 \varepsilon} G_{b}\right)-C_{2 \varepsilon} \rho \frac{\varepsilon^{2}}{k}+S_{\varepsilon} \\
\frac{\partial}{\partial t}(\rho k)+\frac{\partial}{\partial x_{i}}\left(\rho k u_{i}\right)=\frac{\partial}{\partial x_{j}}\left(\alpha_{k} \mu_{e f f} \frac{\partial k}{\partial x_{j}}\right)+G_{k}+G_{b}-\rho \varepsilon+S_{k}
\end{gathered}
$$


And also the mass continuity equation or mass conservation equation is

$$
\frac{1}{\rho_{q}}\left[\frac{\partial}{\partial t}\left(\alpha_{q} \rho_{q}\right)+\nabla \cdot\left(\alpha_{q} \rho_{q} \vec{v}_{q}\right)=S_{\alpha_{q}}+\sum_{p=1}^{n}\left(\dot{m}_{p q}-\dot{m}_{q p}\right)\right]
$$

The following equations represent the conservation of momentum

$$
\begin{gathered}
\frac{\partial}{\partial t}(\rho u)+\frac{\partial}{\partial x}(\rho u u)+\frac{\partial}{\partial y}(\rho u v)=-\frac{\partial P}{\partial x}+\frac{\partial \tau_{x x}}{\partial x}+\frac{\partial \tau_{x y}}{\partial y}+\rho g_{x}+F_{x} \\
\frac{\partial}{\partial t}(\rho v)+\frac{\partial}{\partial x}(\rho v u)+\frac{\partial}{\partial y}(\rho v v)=-\frac{\partial P}{\partial y}+\frac{\partial \tau_{x x}}{\partial x}+\frac{\partial \tau_{y y}}{\partial y}+\rho g_{y}+F_{y}
\end{gathered}
$$

And finally the conservation equation of energy will be [11]:

$$
\begin{aligned}
& \frac{\partial}{\partial t}(\rho E)+\frac{\partial}{\partial x}[u(\rho E)]+\frac{\partial}{\partial y}[u(\rho E)] \\
& =\frac{\partial}{\partial x}\left(k \frac{\partial T}{\partial x}\right)+\frac{\partial}{\partial y}\left(k \frac{\partial T}{\partial y}\right)+\rho\left(v g_{x}+u g_{y}\right)
\end{aligned}
$$

So For steady flows, the heat balance of the air-vapor mixture in condenser air-cooler system can be expressed in CFD as:

$$
\begin{aligned}
& \dot{m}_{a} C_{p a} T_{a j}+\dot{m}_{v, j}\left(h_{f g, 0}+C_{p v} T_{a, j}\right) \\
& =\dot{m}_{a} C_{p a} T_{a, j+1}+\dot{m}_{v, j+1}\left(h_{f g, 0}+C_{p v} T_{a, j+1}\right)+\mathrm{d} x \cdot H_{a v}\left(T_{a}-T_{f, i}\right)
\end{aligned}
$$

where $h_{f g, 0}$ is the latent heat of the water. In the above equation, $h_{f g, 0}+C_{p v} T_{a, j}$ is the specific enthalpy of the water vapor and the temperature $T_{a}$ is in Celsius. By re-arranging the terms, dividing both sides of the equation by $\mathrm{d} x$, and taking the limit, Equation (7) can be expressed as:

$$
-\left(\dot{m}_{a} C_{p a}+\dot{m}_{v} C_{p v}\right) \frac{\mathrm{d} T_{a}}{\mathrm{~d} T_{x}}-\left(h_{f g, 0}+C_{p v} T_{a, j}\right) \frac{\mathrm{d} \dot{m}_{v}}{\mathrm{~d} x}=H_{a v}\left(T_{a}-T_{f, i}\right)
$$

The total heat transfer from the air-vapor mixture to the condensate film consists of the sensible heat $Q_{s}$ and the latent heat $Q_{l}$, that is:

$$
\begin{aligned}
Q & =Q_{s}+Q_{l} \\
& =\mathrm{d} x \cdot H_{a}\left(T_{a}-T_{f, i}\right)+\left(\dot{m}_{v, j}-\dot{m}_{v, j+1}\right) h_{v} \\
& =\mathrm{d} x \cdot H_{a v}\left(T_{a}-T_{f, i}\right)
\end{aligned}
$$

After simplification, we obtain

$$
H_{a v}=H_{a}-\frac{h_{v}}{T_{a}-T_{f, i}} \frac{\mathrm{d} \dot{m}_{v}}{\mathrm{~d} x}
$$

where $H_{a v}$ the overall HTC including both the sensible and latent heat, and $h_{v}$ is the heat transported by the water vapor to the condensate film as water vapor is condensed into water liquid.

The rate of condensation can be calculated from the definition for mass transfer coefficient, which can be expressed as

$$
\mathrm{d} \dot{m}_{v}=\left(\dot{m}_{v, j}-\dot{m}_{v, j+1}\right)=\mathrm{d} x \cdot K\left(C_{v}-C_{v, i}\right)
$$

where $K$ is the mass transfer coefficient of the water vapor, $C_{v}$ is the average 
concentration of water vapor in the air-vapor mixture and $C_{v, i}$ is the water-vapor concentration at the interface between the mixture and the condensation, which depends on interface temperature $T_{f, i}$.

\section{Simulation of Model}

\subsection{Geometry Creation}

Because of limitations in solving the whole 4996 millimeters length of aircooler ducts across the condenser, the geometry of Aircooler ducts in Gambit software is modeled as a 2D model same as Figure 6 and for better concentration in Aircooler performance, only zone 2 is considered, where the cooling tubes existed and condensation will happen. Gambit is the program used to grid or mesh for the CFD solver.

The pre-requirements of gambit software modeling are geometry design, meshing and grid independency check as follows:

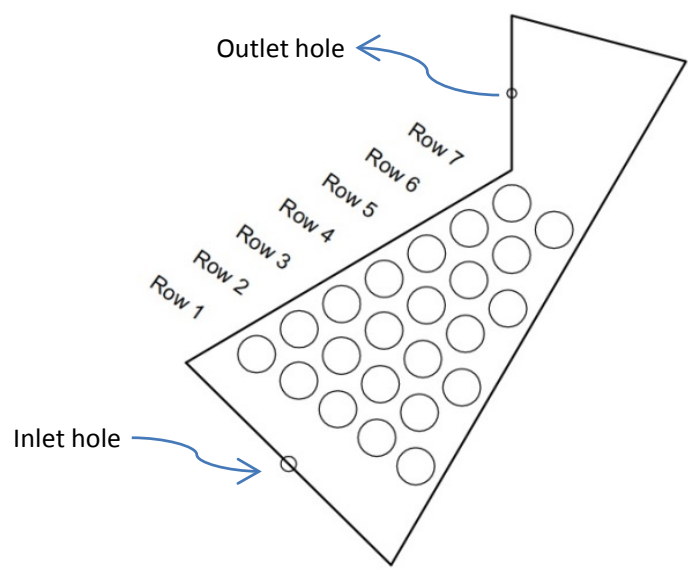

Figure 6. 2D model of aircooler zone 2.

\subsection{Boundary Conditions}

The 2D model consists of 9.8 millimeters inlet hole which steam and air enter and 6.1 millimeters outlet hole where only the air exhausts and also 23 cooling tubes which are considered as a fixed wall temperature according to seawater mean temperature values (Table 1 ). The inlet mixture fluid specifications are according to condenser condition which is directly equal with turbine steam exhaust pressure and temperature.

Table 1. Temperature average data.

\begin{tabular}{lcccc}
\hline \multicolumn{1}{c}{ Season } & Spring & Summer & Fall & Winter \\
\hline $\begin{array}{l}\text { Condenser inlet cooling water average temp }{ }^{\circ} \mathrm{C} . \\
\text { Condenser outlet cooling water average temp }{ }^{\circ} \mathrm{C} .\end{array}$ & 20 & 32 & 22 & 11 \\
$\begin{array}{l}\text { Turbine exhaust average temp. @ condenser } \\
\text { steam side }{ }^{\circ} \mathrm{C} \text {. }\end{array}$ & 42 & 58 & 47 & 37 \\
$\begin{array}{l}\text { Turbine exhaust average press. @ condenser } \\
\text { steam side }{ }^{\circ} \mathrm{C} \text {. }\end{array}$ & 92 & 81 & 89 & 94 \\
\hline
\end{tabular}




\subsection{Grid Independence and Meshing}

For analyzing the Aircooler system in fluent software it is necessary to create a mesh structure. The mesh structure specifies the resolution at which FLUENT ${ }^{\circledR}$ analyses the model. Therefore, a grid independence study was carried out to ensure the results accuracy Figure 7 shows the mesh independency as the temperature variations of mixture gas through aircooler cooling tubes in different mesh size.

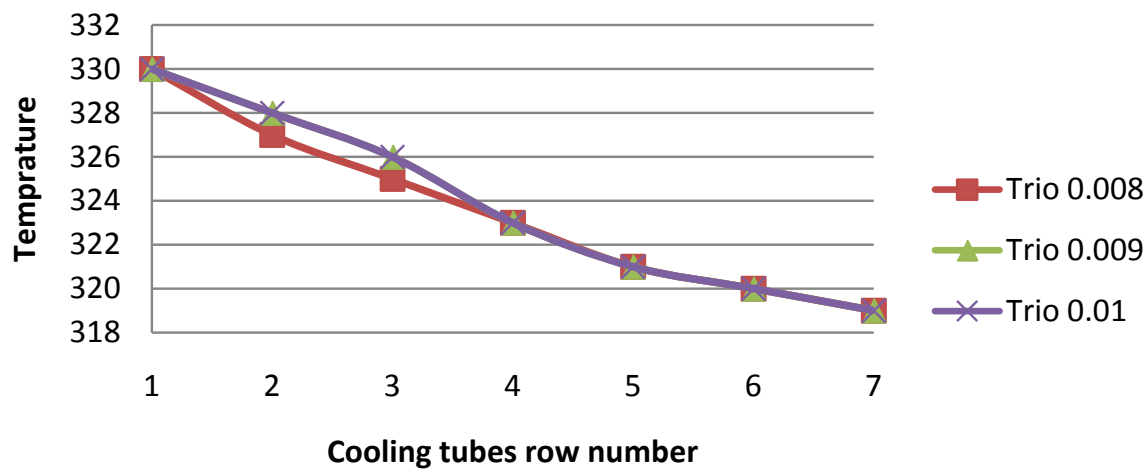

Figure 7. Mixture temperature variation through cooling tube rows in zone 2.

\subsection{Results Validation}

To validate the CFD results, according to Figure 8 a temperature gage was installed at the aircooler exhaust suction pipe to ejector, so the temperature variation by CFD method and real situation is shown in Figure 9.

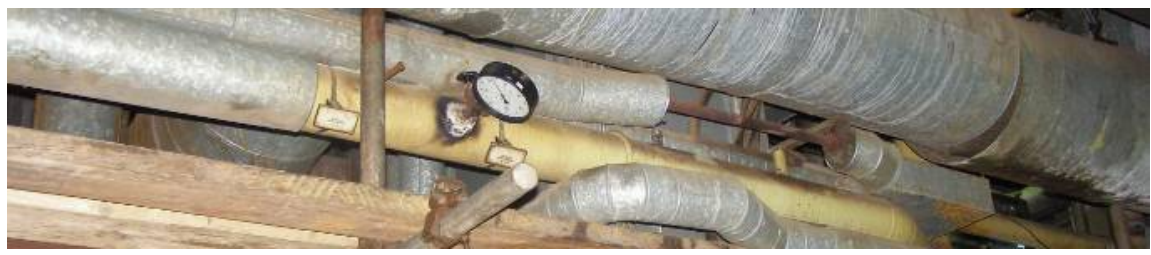

Figure 8. Temperature gage installed to aircooler exhaust suction line to ejector.

\section{Aircooler Exhaust temperature validation}

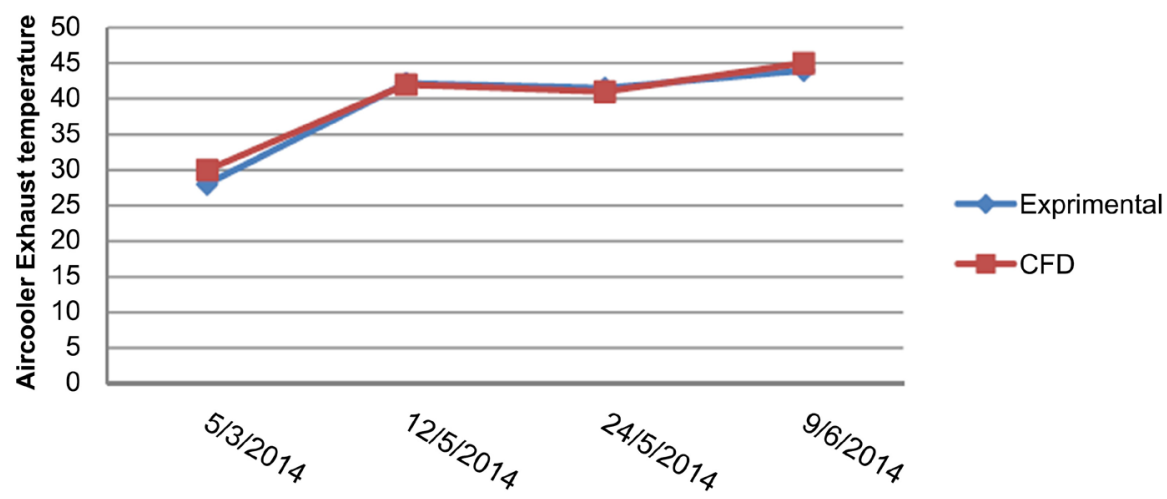

Figure 9. Temperature variation in exhaust of aircooler. 


\section{Results and Discussion}

\subsection{Aircooler Normal Condition Analysis}

Figure 10 shows CFD results of the variation of steam-air mixture velocity through the first two rows of aircooler zone 2 in different seasons.

And also the variation of exhaust temperature at the end of zone 2 to zone 3 which shows the capability of aircooler to reduce the mixture temperature for better performance of ejector is shown in Figure 11.

The results according to Figures 10-12 show that in hot season of year the mixture velocity to the first row of cooling tubes in aircooler zone 2 will be increased which can be the major reason of tube rupture in hot seasons of year.

Furthermore according to Figure 13 in hot seasons of year the efficiency of aircooler zone 2 will be reduced due to low capability of reducing the aircooler exhaust temperature.

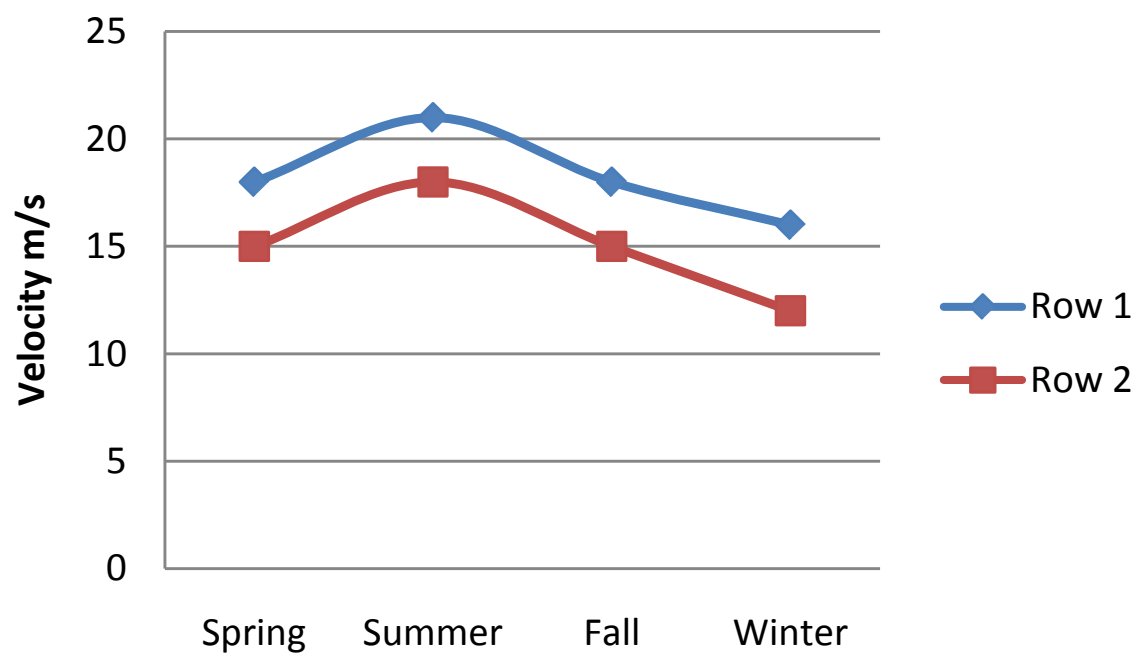

Figure 10. Variation of mixture velocity through first two rows of aircooler zone 2.

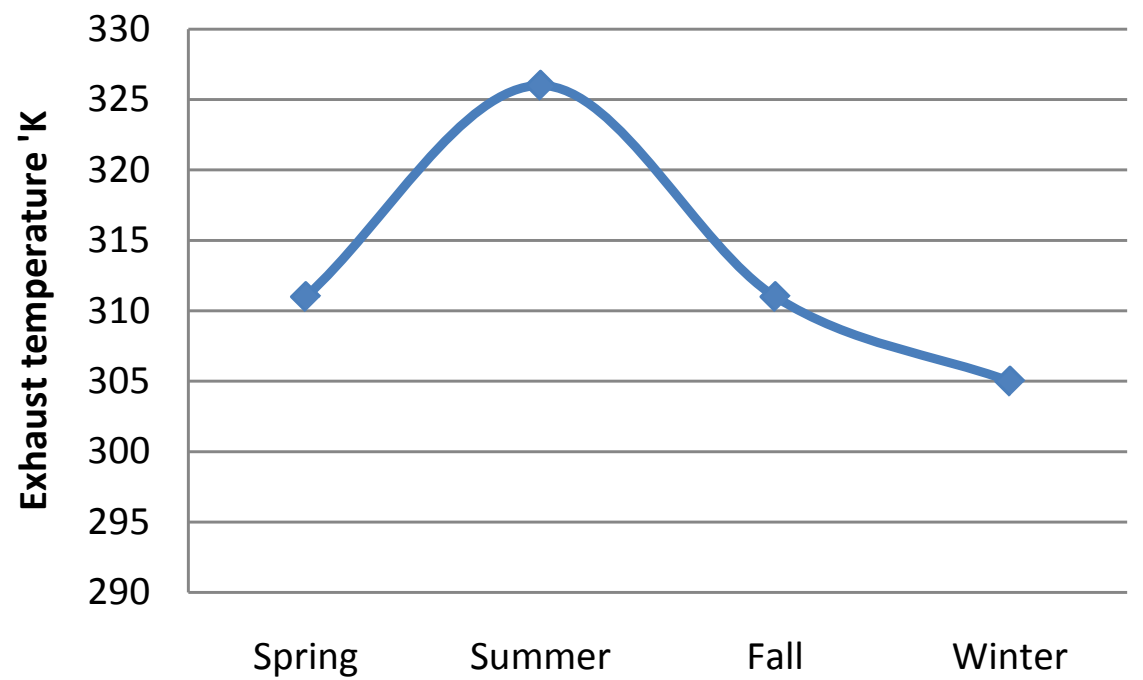

Figure 11. Variation of temperature at the exhaust of aircooler zone 2. 

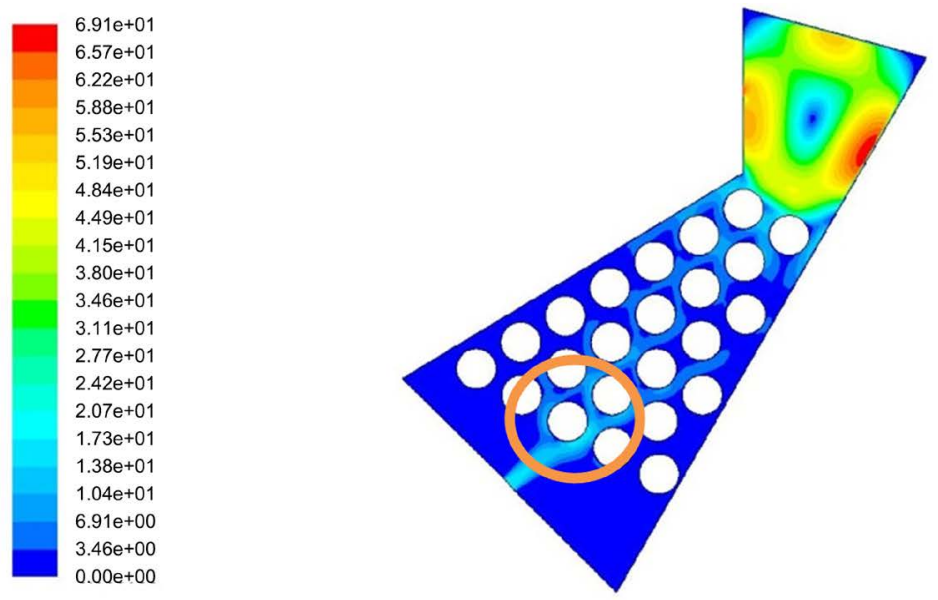

Contours of Velocity Magnitude (mixture) $(\mathrm{m} / \mathrm{s})$

Figure 12. Velocity contour in Aircooler zone 2.

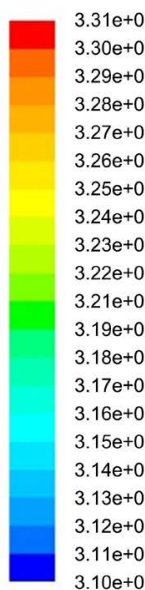

$3.31 \mathrm{e}+02$
$3.30 \mathrm{e}+02$
$3.29 \mathrm{e}+02$
$3.28 \mathrm{e}+02$
$3.27 \mathrm{e}+02$
$3.26 \mathrm{e}+02$
$3.25 \mathrm{e}+02$
$3.24 \mathrm{e}+02$
$3.23 \mathrm{e}+02$
$3.22 \mathrm{e}+02$
$3.21 \mathrm{e}+02$
$3.19 \mathrm{e}+02$
$3.18 \mathrm{e}+02$
$3.17 \mathrm{e}+02$
$3.16 \mathrm{e}+02$
$3.15 \mathrm{e}+02$
$3.14 \mathrm{e}+02$
$3.13 \mathrm{e}+02$
$3.12 \mathrm{e}+02$
$3.11 \mathrm{e}+02$
$3.10 \mathrm{e}+02$

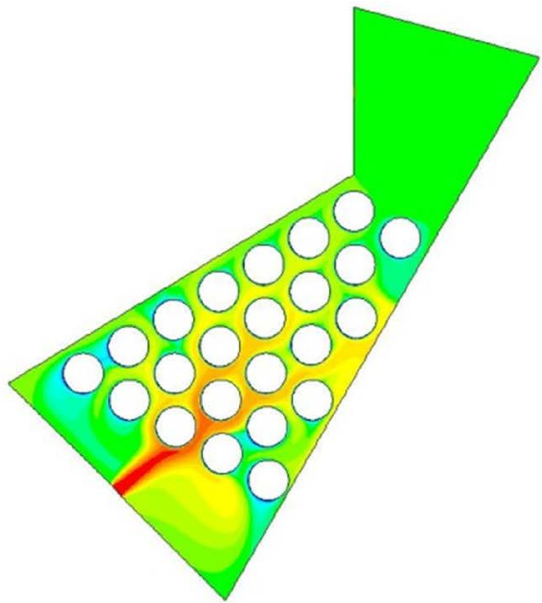

Contours of Static Temperature (mixture) (k)

Figure 13. Temperature contour in Aircooler zone 2.

\subsection{Redesign Aircooler Ducts}

To reduce the risk of tube rupture in aircooler zone 2, the two optimized designs of aircooler ducts are predicted which first reduces the mixture velocity to the first and second rows of cooling tubes and second reduces the exhaust temperature of aircooler to ejector which can cause the better performance of ejector

\subsubsection{Aircooler Modified Plan 1}

In this design, as shown in Figure 14, the inlet section of zone 2 will draw back to zone 1 and also the inlet hole situation, changed to center the inlet flow, where by this design the diffused shape of, new model helps to diffuse the mixture inlet flow and the velocity to the first row will decreases.

The new aircooler modified plan 1 velocity contour is shown in Figure 15.

The results revealed that in new design 1 the mixture velocity to first row of 
cooling tubes was reduced to $28 \%$ and aircooler exhaust temperature reduced 1 degrees of kelvin (Figure 16 \& Figure 17).
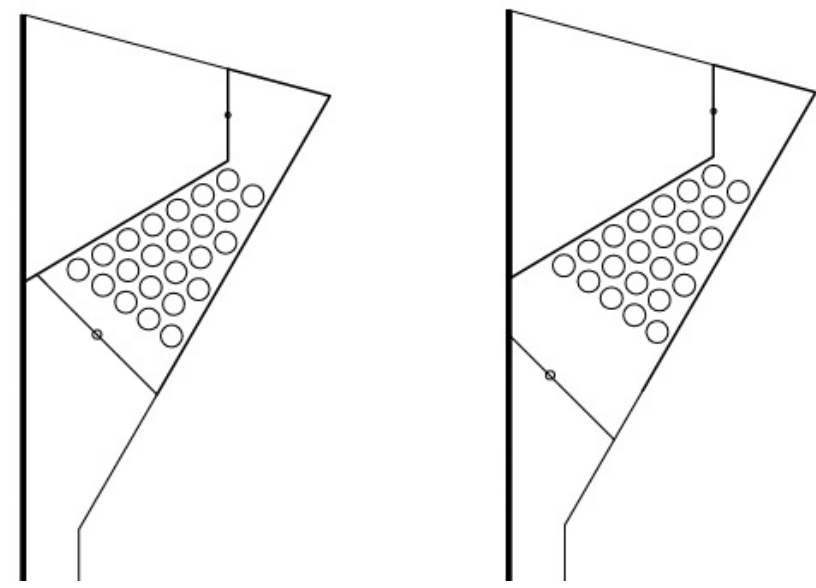

Figure 14. The new aircooler modified plan 1 changes.
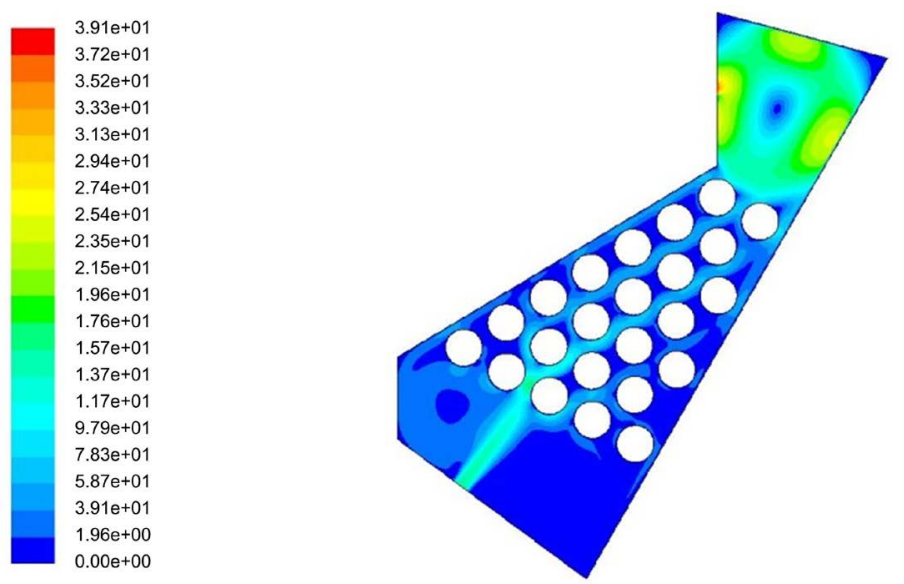

Contours of Velocity Magnitude (mixture) $(\mathrm{m} / \mathrm{s})$

Figure 15. New design velocity contour.

\section{Mixture velocity at first cooling tube row}

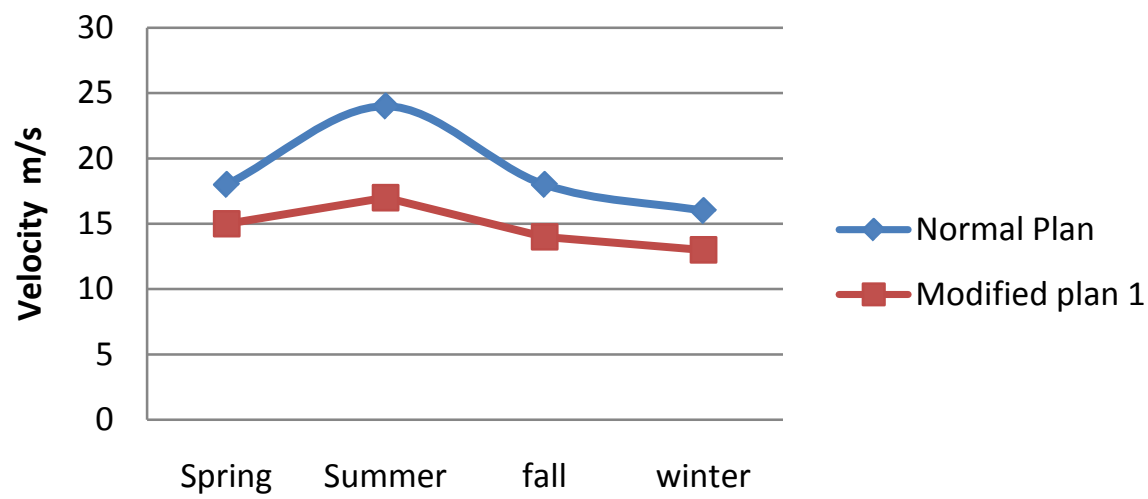

Figure 16. Mixture velocity variation to first cooling tubes row. 


\section{Aircooler exhaust temperature}

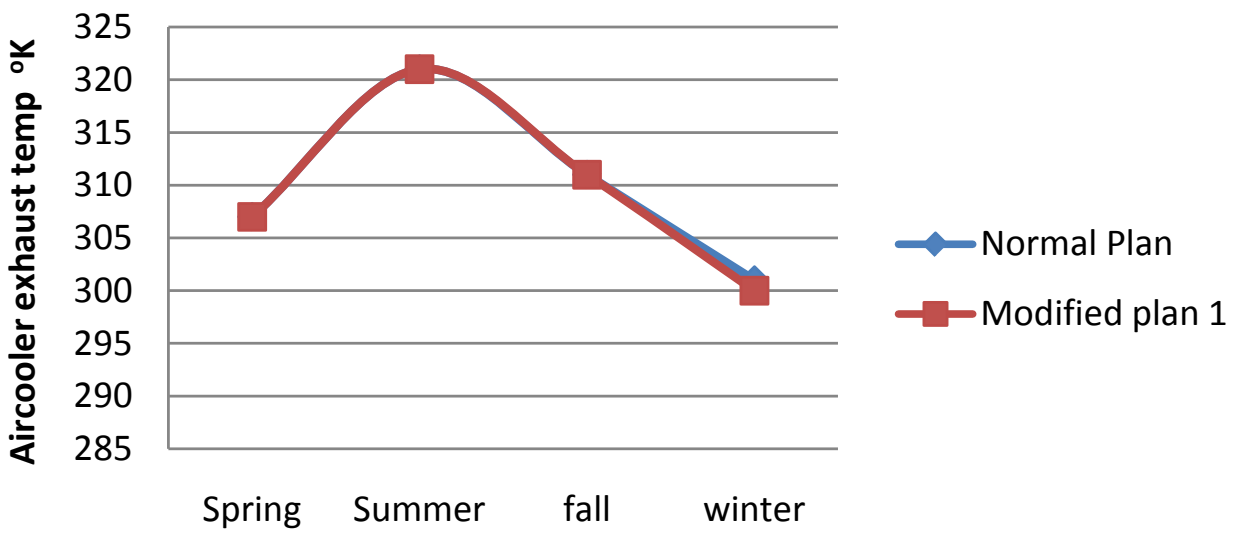

Figure 17. Temperature variation of aircooler zone 2 exhaust.

\subsubsection{Aircooler Modified Plan 2}

In new design 2 the basic shape of aircooler ducts are remained fixed but each 9.8 millimeters inlet holes turns to two 7 millimeters holes across the width of zone 2 inlet duct.

In this case, by remaining the suction holes area to constant value, the mixture flow separated into two flows which disperse in cooling tubes more than before

The new design 2 velocity contour is shown in Figure 18.
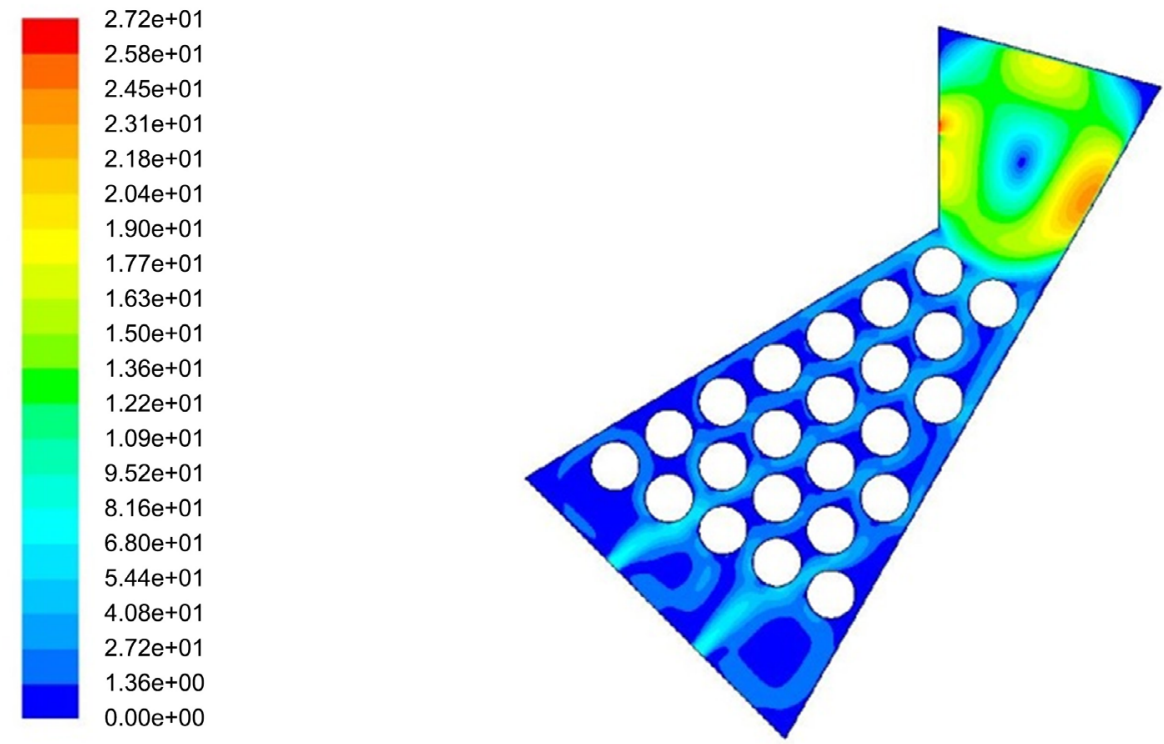

Contours of Velocity Magnitude (mixture) $(\mathrm{m} / \mathrm{s})$

FLUENT 6.3 (2d, dp, pbns, vof, spe, rngke)

Figure 18. Velocity contour of new design 2 aircooler zone 2.

The results revealed that in new design 2 the mixture velocity to first row of cooling tubes was reduced to $60 \%$ and aircooler exhaust temperature reduced 3 degrees of kelvin (Figure 19 \& Figure 20). 


\section{Mixture velocity at first cooling tube row}

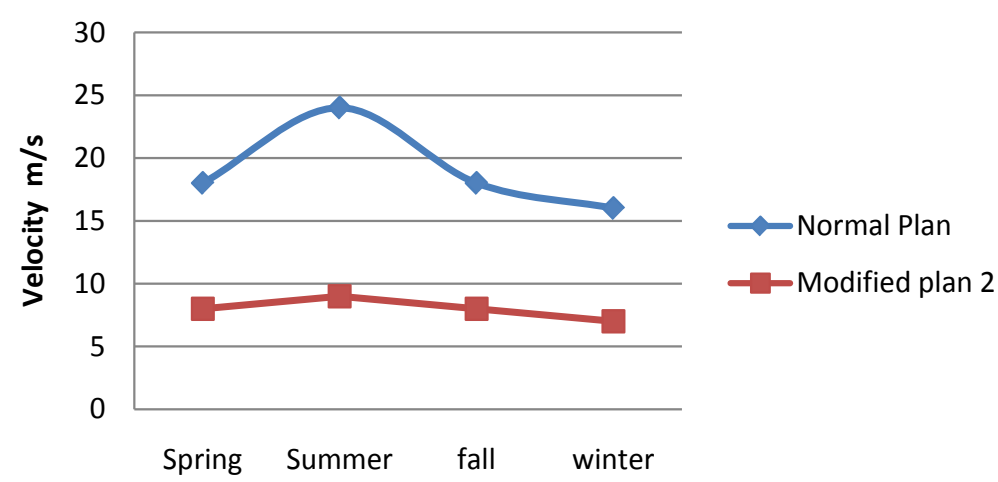

Figure 19. Mixture velocity variation to first cooling tubes row.

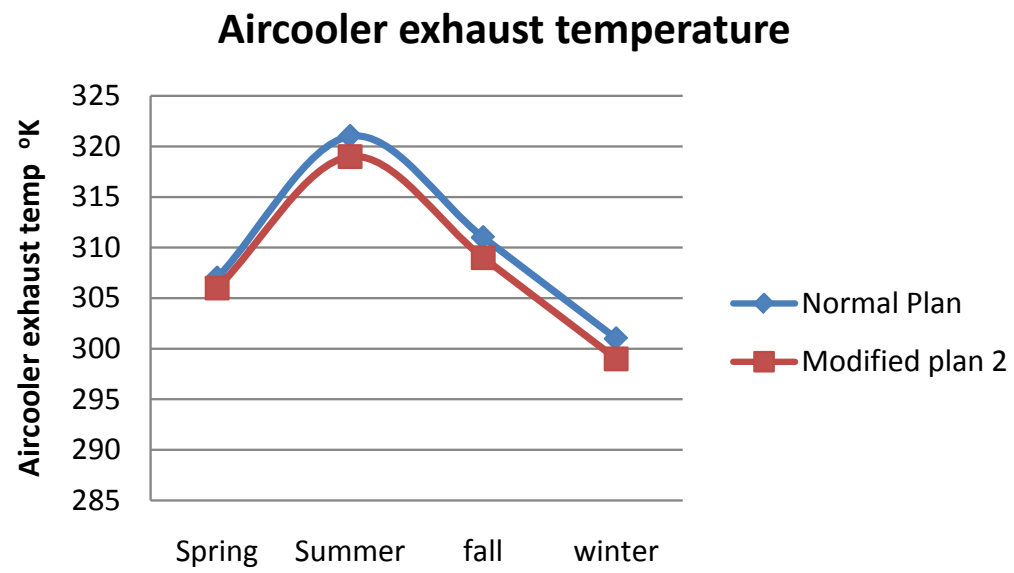

Figure 20. Temperature variation of aircooler zone 2 exhaust.

\section{Conclusions}

In this paper the mixture of two-phase fluid flow in a condenser aircooler is studied and also the condensation in zone 2 of aircooler has been simulated.

First, the critical condition where tube rupture happens was determined and showed that in hot seasons of year by increasing the seawater cooling temperature and increasing in turbine exhaust steam pressure and temperature, the risk of tube rupture has been increased due to the higher velocity of steam and air mixture flow to the first row of aircooler cooling tubes and this causes the tube rupture. This phenomenon emphasized that the increasing in velocity of mixture flow to the aircooler cooling tubes leads to the dezincification of tubes and increasing the tube rupture.

Finally, two aircooler designs at the ducts were studied which showed that by modification of aircooler ducts and holes, the risk of tube rupture has decreased remarkably.

This happened only by decreasing the mixture flow velocity to the first aircooler cooling tube rows and also another result of these modifications caused the exhaust temperature of aircooler to decrease and lead to higher ejector performance (Figure 21 \& Figure 22). 
Mixture velocity at first cooling tube row

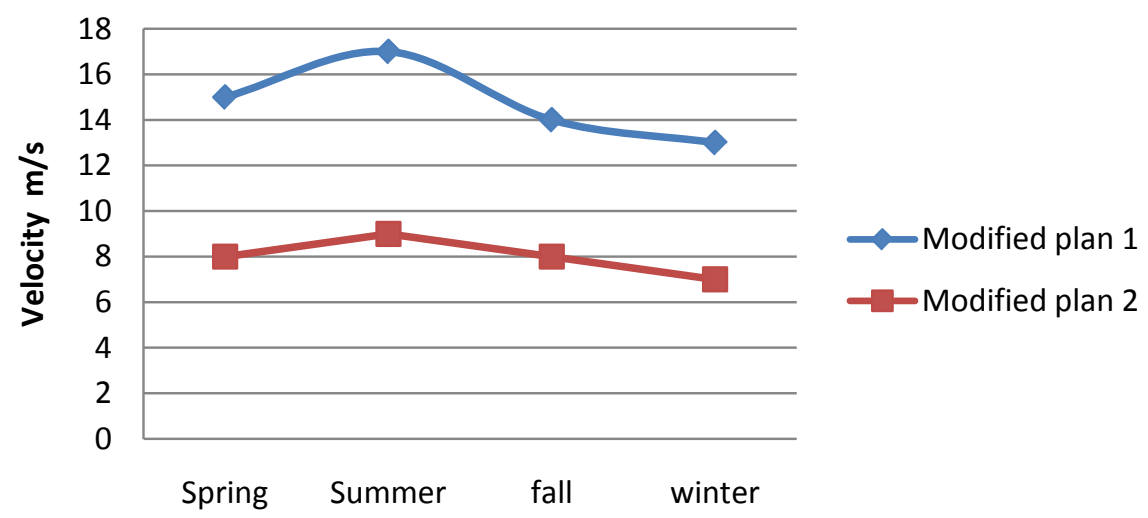

Figure 21. Mixture velocity variation to first cooling tubes row.

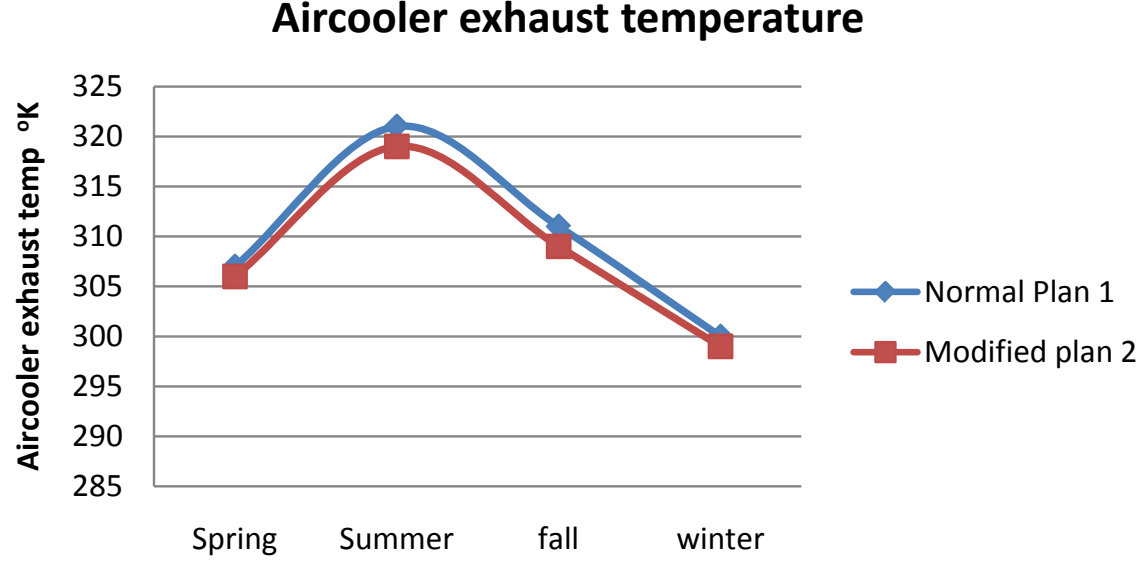

Figure 22. Temperature variation of aircooler zone 2 exhaust.

For further study of aircooler design or modifications that affect the performance of aircooler, the following items are recommended to be included:

1) More aircooler ducts modifications (modification in structural design);

2) Considering the tube material change in aircooler performance;

3) Considering the tube thickness "BWG" in aircooler performance;

4) Considering the ejector suction flow on aircooler performance.

\section{Conflicts of Interest}

The authors declare no conflicts of interest regarding the publication of this paper.

\section{References}

[1] El Wakil, M.M. (2002) Powerplant Technology. McGraw-Hill Science, USA.

[2] Van Wylen, G.J. and Sonntag, R.E. (1986) Fundamentals of Classical Thermodynamics. 3rd Edition, Wiley, New York.

[3] Lux, J.J., Razgaitis, R., Ball, D.A. and Locklin, D.W. (1983) Development of an Analytical Design Technique for Condensing Flue-Gas Heat Exchangers. International 
Gas Research Conference, London.

[4] Malalasekera, W.M.G., James, E.H., Tayali, N.E. and Lee, L.E.K. (1993) Flow and Heat Transfer in the Secondary Heat Exchanger of a Condensing Boiler. American Society of Mechanical Engineers, 29 th National Heat Transfer Conference, Atlanta, Georgia, August 1993, 83-92.

[5] Valencia, M.P.P. (2004) Condensation of Water Vapour and Acid Mixtures from Exhaust Gases, Ph.D. Thesis, Technical University of Berlin, Germany.

[6] Karkoszka, K. and Anglart, H. (2006) CFD Modelling of Laminar Film and Spontaneous Condensation in Presence of Noncondensable Gas. Archives of Thermodynamics, 27, 23-36.

[7] Ambrosini, W., Bucci, M., Forgione, N., Oriolo, F., Paci, S., Magnaud, J.P., Studer, E., Reinecke, E., Kelm, S. and Jahn, W. (2008) Comparison and Analysis of Thecondensation Benchmark Results. The 3rd European Review Meeting on Severeaccident Research (ERMSAR-2008), Nesseber, Bulgaria, 23-25 September 2008.

[8] Benelmir, R., Mokraoui, S. and Souayed, A. (2009) Numerical Analysis of Film Wise Condensation in a Plate Fin-And-Tube Heat Exchanger in Presence of Non-Condensable Gas. Heat and Mass Transfer, 45, 1561-1573.

https://doi.org/10.1007/s00231-009-0531-8

[9] Saraireh, M. (2012) Heat Transfer and Condensation of Water Vapor from Humid Air in Compact Heat Exchangers, Engineering and Science Victoria University Melbourne, Australia.

[10] BBC. Instruction Manual, Mazandaran Thermal Power Plant $4 \times 440 \mathrm{MW}$.

[11] Brennen, C.E. (2005) Fundamentals of Multiphase Flows. Cambridge University Press, Cambridge, England. https://doi.org/10.1017/CBO9780511807169 